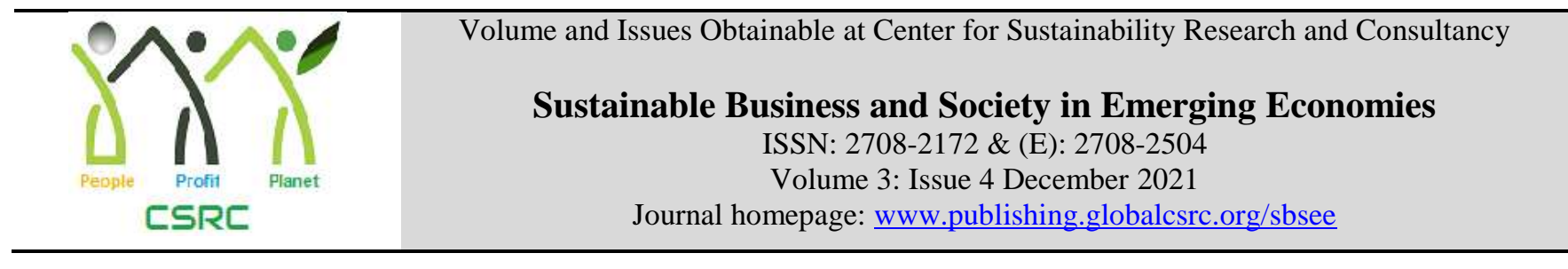

\title{
Poverty Human Capital and Economic Development Nexus: A Case Study of Multan Division
}

*Salyha Zulfiqar Ali Shah, School of Economics, Bahauddin Zakariya University Multan, Pakistan Imran Sharif Chaudhry, School of Economics, Bahauddin, Zakariya University Multan, Pakistan Fatima Farooq, School of Economics, Bahauddin Zakariya University Multan, Pakistan

*Corresponding author's email address: salyhazulfiqar@bzu.edu.pk

\begin{tabular}{l} 
ARTICLE DETAILS \\
\hline History \\
Revised format: Nov 2021 \\
Available Online: Dec 2021 \\
\hline Keywords \\
Poverty, Human Capital, \\
$\begin{array}{l}\text { Economic Development, Per } \\
\text { capita income, Poverty } \\
\text { alleviation }\end{array}$
\end{tabular}

JEL Classification

I32, C21, D1, P46

\section{OPEN $\rightarrow$ ACCESS}

\section{ABSTRACT}

Purpose: Countries across the world have acknowledged that poverty alleviation has to be of critical importance among the objectives of economic development. This paper sheds light on the Multan division, as one of the important divisions of Southern Punjab, Pakistan.

Design/Methodology/Approach: The primary data was collected through a household survey during the year 2019, using the Binomial Logit and Ordinary Least Squares (OLS) regression techniques.

Findings: The study concluded that the occupation of the household head in the primary sector and large household size are significant and positively related to household poverty. However, the human capital of the household is found to be significant and negatively related to household poverty in the Multan division. Economic development or per capita income of the households are found to be significant and positively related to the human capital of the households.

Implications/Originality/Value: The provision of job opportunities by the government would be helpful in poverty alleviation and the development of this region.

(C) 2021 The authors, under a Creative Commons AttributionNonCommercial- 4.0

Recommended citation: Shah, S, Z, A., Chaudhry, I, S. and Farooq, F. (2021). Poverty Human Capital and Economic Development Nexus: A Case Study of Multan Division. Sustainable Business and Society in Emerging Economies, 3 (4), 461-469

\section{Introduction}

The elimination of high and widespread poverty is at the core of all the development issues and problems. People suffering from poverty are mal-nutrient, in poor health conditions, living in slumps areas and forced to adopt a subsistence lifestyle due to low-paid jobs. Children account for half of the population living in extreme poverty, out of which three-fourth belongs to Asia and Sub-Saharan Africa [UNICEF, (2016)]. UNICEF (2017), reported that in poor regions like Sub-Saharan Africa, one child out of 36 dies during the first month of birth. On contrary, it is one child out of 333 dies during the first month of birth in developed countries. World Bank (2015), declared new global poverty estimates from 1981 to 2015, that upgrade the international poverty line to $\$ 1.90$ a day based on the year 2011-12 Purchasing Power Parity (PPP). UNDP (2018), reported that 1.3 billion people belonging to poor countries are part of the multidimensional poverty. 
Education is the fundamental right of every individual. Children belonging to poor families often lack access to basic socio-economic rights like education and health facilities. Numerous reasons, maybe their parents are poor enough to afford their school fees, maybe the lack of good quality schools are unavailable in their remote areas or maybe the children are working in petty jobs to support financial help to their families. Pakistan is a developing country and facing numerous challenges relating to the issue of economic prosperity, household poverty, high unemployment, low literacy rates, poor health, malnutrition, polluted environment, unequal distribution of income and inflation, all leading to low macroeconomic performance and growth rates. Higher Gross National Income (GNI) is a prerequisite for economic development resulting in sustained growth. The present study focuses on the Multan division, which is one of the important divisions of Southern Punjab Pakistan. Poverty is gradually increasing in the Multan division, due to the low employment opportunities and lack of resources. Considering the problem of economic development, human capital and rising household poverty in the Multan division. The present study has been focused to analyze the nexus between human capital, poverty and economic development in the Multan division.

This paper is structured as follows. Section 2, presents a brief overview of existing literature. Section 3 offers data and methodology. Section 4 explains the empirical findings. Section 5 provides the concluding remarks.

\section{The Literature Review}

This section provides some pieces of research regarding poverty, human capital and economic development from different researchers across the world.

\section{Poverty}

Rodriguez and Smith (1994) found that poverty prevails in those households, headed by a person having lower education attainment. Shirazi (1995) studied the determinants of poverty in Pakistan. The author has collected secondary data from the Household's Income and Expenditure Survey (HIES) during the year 1987-88, using the Logit model technique. The study has found that those households receiving sadaqaat were facing less poverty. House household headed by an educated person is less likely to be poor. Among all provinces, poverty prevails more in Punjab as compared to the other provinces. It was also noted that households having a large number of earners are less prone to poverty. However, large household size increases the incidence of poverty.

Datt and Jolieffe (1999) had scrutinized the major causes of poverty in Egypt for the year 1997. The authors had collected secondary data, using multivariate analysis. The study revealed that education can play a vital role in alleviating poverty. If the adult average years of schooling were improved, this would result in a better standard of living for households. An investment in education can raise human capital resources and thus lower the poverty incidence for the long term. The policy implication suggested that better irrigation facilities can help generate employment opportunities thus reducing the rate of unemployment but also an increase in the productivity of the agriculture sector in Egypt.

Akinbode (2013) examined the profile and determinants of poverty in the southwest region of Nigeria during the year 2013. The author has collected data from urban households using the Ordinary Least Squares (OLS) regression technique. The dependent variable was household welfare which was proxy by per capita consumption expenditure. The study has found a positive relationship between the education of household heat and per capita consumption expenditure. This showed that education results in better income and future earnings. access to credit was also an important indicator of household welfare. The government should generate employment opportunities and introduce different programs to lower down dependency ratio so that poverty can be eliminated. 


\section{Human Capital}

Becker (1995) compared and analyzed various studies regarding the determinants of human capital. The various factors represent human capital i.e. values, education (secondary, elementary, primary), expenditure on schooling, on-the-job training, innovative entrepreneurs, skills, knowledge, health, habits, etc. Many countries like Japan, Korea and Taiwan had less natural endowments but achieved economic growth due to their well-educated, well-trained and hardworking labor force. An investment in human capital raises the standard of living of the people and thus alleviates Poverty. Birth rate, large family size showed a negative relationship with economic growth. High population rates and mortality rates can only be reduced by educating females at the secondary and elementary levels. Education and growth reduce inequality and those countries which were considered poor because of their unequal investment in education i.e. Human capital. Effective utilization of trained persons and efficient working of the organization and an active economic system would be crucial factors for sustainable economic growth.

Lee and Francisco (2010) analyzed the correlates of human capital in emerging Asia. The author presented the role of human development from 1970 to 2010 and educational progress for the upcoming 20 years. Parent's income and education, income distribution, number of children, government policy and ethics were discussed in the study. The dependent variable was enrollment rate and explanatory variables were real GDP per capita, Gini-coefficient, average years of schooling, total fertility rate and education expenditure. The study concluded that the parent's income and education would improve the child's education. The higher the education of females, the lower will be the fertility rates. Lower-income inequality and diminishing fertility rates would improve the economic conditions of East Asia.

\section{Economic Development}

Frankel and Romer (1999) examined the role of trade in generating economic growth and development. The authors have collected data from the direction of trade statistics and Penn world table during the year 1985 for 63 countries. The finding derived from the study showed that a one percent increase of trade to GDP ratio will increase the income of a person by one and a half percent. Trade plays a positive relationship in the economic growth of these counties. Trade generates physical and human capital that will increase production depending upon capital accumulation. The government should formulate trade promotion policies to generate trade and economic growth.

Pede et al. (2011) examined the factors that affect the economic status of the household in the Philippines. The author collected cross-section data from four provinces, using the Ordinary Quantile regression technique. The results concluded that farmers living near urban areas have a low income as compared to the farmers living in rural areas. Similarly, farmers living near urban areas are participating in off-farm activities as compared to the farmer living in rural areas. Those households having migrated workers have more income as compared to others. As joint families have a large household size and significantly contribute to the household income. it was also revealed that educated farmers earn more income as they adopt new farming technologies, which help raise their income and productivity.

\section{Data and Methodology}

The primary data has been collected through a household survey in the Multan division during the year 2019. The area of the Multan division is $17,935 \mathrm{~km}^{2}$. It consists of four districts. Multan district, Vehari district and Khanewal district and Lodhran district. The sample size consists of 377 households and the interview has been conducted from household-head, adopted simple random and stratified sampling techniques.

\section{Multiple Regression Analysis}

In the present study, the simplest technique for analyzing the poverty model i.e., Binomial Logit has been utilized for econometric analysis. To analyze the factors affecting human capital and economic development, Ordinary Least Squares (OLS) regression has been employed to study the nexus between Poverty, human capital and economic development in the Multan division. 
It starts with a general function,

$$
Y_{i}=f\left(X_{1}, X_{2} \ldots \ldots . X_{n}\right)
$$

Where " $Y_{i}$ " indicates Poverty. $Y$ is equal to " 1 " if poverty exists in the household and equal to " 0 " if poverty does not exist in the household... $X_{1}, X_{2} \ldots \ldots \ldots X_{n}$ represents different socio-economic and demographic variables.

We construct the following model.

$$
Y_{i}=\alpha+\beta_{1} X_{1 i}+\beta_{2} X_{2 i}+\beta_{3} X_{3 i \ldots \ldots \ldots} \beta_{K} X_{j}+u_{i}
$$

Where $X_{j}$ is a set of ${ }_{\mathrm{j}}$ th independent variables where $\mathrm{j}=1,2, \mathrm{k}$.

If the dependent variable of the model is in the form of dichotomous or dummy, then

The logistic regression model can be explained through the equation:

$$
Y^{*}=\beta_{1}+\beta_{2} X 2 i+\beta_{3} X 3 i+\ldots \ldots \ldots \ldots \ldots \ldots .+\beta_{k} X_{k i}+\epsilon_{i}
$$

$\mathrm{Y}^{*}$ is the dependent variable representing the Households' level of poverty and $\mathrm{Xs}$ are the various household-level socioeconomic and demographic indicators that determine the household level poverty determinants Being a dummy or a dichotomous variable $\mathrm{Y}$ can be written in the form of

$$
Y_{i}=1, \quad \text { if } Y_{i}<0 ; \quad Y_{i}=0
$$

\begin{tabular}{|c|c|c|}
\hline Variables & & The Description of the Variables \\
\hline \multicolumn{3}{|c|}{ Dependent Variable for Binomial Logit Model } \\
\hline Y & Poverty & $\begin{array}{l}=1 \text { if per capita income is lower than } \$ 1.90 / \text { day then the } \\
\text { household is Poor } \\
=0 \text { if per capita income is more than } \$ 1.90 / \text { day then the } \\
\text { household is non-Poor }\end{array}$ \\
\hline \multicolumn{3}{|c|}{ Dependent Variable for OLS Regression Model } \\
\hline LNPCI & Log of Per Capita Income & $\begin{array}{l}\text { It is the proxy for Economic Development. It is the natural log of } \\
\text { per capita income. }\end{array}$ \\
\hline $\mathrm{HCI}$ & Human Capital Index & $\begin{array}{l}\text { It is the proxy for Human Capital. It is an index constructed by } \\
\text { considering the household's education and health-related factors. }\end{array}$ \\
\hline \multicolumn{3}{|r|}{ Independent Variables } \\
\hline \multicolumn{3}{|c|}{ Demographic Variables } \\
\hline HSIZE & Household 's Size & The total person in a household \\
\hline \multicolumn{3}{|c|}{ Economic Variables } \\
\hline $\mathrm{OCC}$ & $\begin{array}{l}\text { Occupation of Household } \\
\text { Head }\end{array}$ & $\begin{array}{l}=1 \text { if household head working in the primary sector } \\
=0 \text { if household head not working in the primary sector }\end{array}$ \\
\hline NOEIH & Number of Earners & The household comprising of total earners \\
\hline LNVOLPA & Physical Assets & $\begin{array}{l}\text { The natural log of value of physical assets owned by the } \\
\text { household }\end{array}$ \\
\hline REM & Remittances & $\begin{array}{l}=1 \text { if household receive remittances } \\
=0 \text { if a household does not receive remittances }\end{array}$ \\
\hline
\end{tabular}

Thus, logistic equation can be written as

$$
F\left(-\sum X_{i}^{\prime} \beta\right)=\frac{e^{-\sum X_{i}^{\prime} \beta}}{1+e^{-\sum X_{i}^{\prime} \beta}}=\frac{1}{1+e^{\sum X_{i}^{\prime} \beta}}
$$

Table 1: Variables Utilized for Binomial Logit and OLS Regression Estimates

\section{Results of Econometric Analysis of Poverty, Human Capital and Economic Development Nexus in Multan Division}

This section presents the result of an econometric analysis of poverty, human capital and economic development nexus in the Multan division. In Table 2, household poverty is employed as a dependent variable to examine its relationship with human capital and economic development in the Multan division. For this purpose, the Binomial Logistic regression technique has been utilized to analyze the results.

Table 2 presents the result of the econometric analysis presents that the coefficient of human capital shows a negative relationship with household poverty, significant statistically. This means that if the human 
capital of the household is increasing with time, they are less likely to be poor. The marginal effect shows that the likelihood of household poverty reduces by 0.114 percent if the human capital of the household increases by one unit. Over time, households are becoming more educated and skilled, which enables them to get better job opportunities. This allows them to raise their income level and they are less likely to be poor [Chaudhry et al. (2009)]. Similar findings are also concluded by Becker (1995), Narayan-Parker (1999), Narayan (2002) and Adekoya (2018).

The marginal effect shows that there is a 0.346 percent likelihood of increasing household poverty if the occupation of the household head is associated with the primary sector. This shows that the earnings from the primary sector are quite low. Therefore, the income per capita of the households also remains low and are more prone to poverty [Agenor (1996) and Anyanwu, (2014)].

About the household size, it is found that a positive relationship exists between household size and household poverty. This relationship is significant statistically at a 1 percent significance level. It can be interpreted from Table 2, that if the size of household increases by one person, there is a 0.044 percent likelihood of increasing household poverty. The intention might be that households suffering from chronic poverty are living below the poverty line having low per capita income due to large family size. Hence, they are forced to live in poverty [Arif and Bilquess (2007), Litchfield and McGregor 2009) and Arif and Farooq (2014)].

The coefficient of worker's remittances and the value of physical assets are found to be statistically insignificant and no relationship with poverty has been found in the Multan division. The McFadden Rsquared of the model is 0.408 . The LR statistics is 200.516 and the p-value is 0.000 , which is significant statistically.

Table 2: Binomial Logistic Regression Results of Poverty, Human Capital and Economic Development Nexus in Multan Division

\begin{tabular}{|c|c|c|c|c|c|}
\hline \multicolumn{6}{|c|}{ Dependent Variable: Poverty (if Poverty =1, Otherwise = 0) } \\
\hline Variable & Coefficients & $\begin{array}{c}\text { Standard } \\
\text { Errors }\end{array}$ & z-Statistic & P-value & $\begin{array}{c}\text { Marginal } \\
\text { Effects }\end{array}$ \\
\hline Constant & 0.874 & 1.234 & 0.708 & 0.479 & --- \\
\hline Human Capital & -0.527 & 0.079 & -6.643 & 0.000 & -0.114 \\
\hline Remittances & -1.024 & 0.745 & -1.374 & 0.169 & -0.221 \\
\hline $\begin{array}{l}\text { Occupation of the } \\
\text { Household Head }\end{array}$ & 1.603 & 0.354 & 4.531 & 0.000 & 0.346 \\
\hline $\begin{array}{l}\text { Value of the Physical } \\
\text { Assets } \\
\end{array}$ & -0.046 & 0.071 & -0.648 & 0.517 & -0.010 \\
\hline Household Size & 0.204 & 0.060 & 3.427 & 0.001 & 0.044 \\
\hline \multicolumn{2}{|l|}{ McFadden R-squared } & 0.408 & \multicolumn{2}{|c|}{ Mean dependent var } & 0.358 \\
\hline \multicolumn{2}{|l|}{ LR statistic } & 200.516 & \multicolumn{2}{|c|}{ Prob. (LR statistic) } & $(0.000)$ \\
\hline
\end{tabular}

Source: Survey data, 2019

In Table 3, the human capital is the dependent variable to analyze its relationship with household poverty and economic development in the Multan division. For this purpose, the human capital index is constructed and employed as a proxy for human capital. The Ordinary Least Squares (OLS) regression technique is used for the econometric analysis.

Regarding the poverty situation of the household, the results of the econometric analysis turned out to be a negative relationship between household poverty and the human capital index or human capital of the household. This relationship is significant statistically at the 5 percent significance level. The results conclude that if household poverty rises by one unit, it will reduce the human capital index or human capital by 0.951 units. Poor households do not have the potential to spend on education and social needs due to the low level of earnings. If they further fall below the poverty line, it will be difficult for them to manage their livelihood for their survival [Warren et al., (2001), Attanasio et al., (2017)]. 
Considering the income per capita, the estimates of the results show a positive relationship between human capital and per capita earnings. Table 3 infers that if earning per capita of the household rises to one percent, it will increase the human capital index or human capital of the household by 1.113 units. This connection is found to be statistically significant. A rise in earnings will improve the standard of living of the households. This induces them to spend on their education and health needs. This result shows that economic development acts as a catalyst in accelerating the human capital of the region especially in poor countries like Pakistan. [Benhabib and Speigel (1994), Knowles and Owen (1995)

Another important source of household income is the worker 's remittances, which have a significant influence on human capital. In this analysis, the influence of remittances on human capital is elaborated to be positive. This association is found to be significant statistically at a 5 percent significance level. The results from Table 3 infers that as the remittances increase by one unit the human capital index or human capital of the household increase by 0.756 unit. Remittances support the households economically or financially to improve their standard of living. This allows them to raise their future earnings. The same results are concluded by Adenutsi (2010).

Results from Table 3 shows that as the number of an earner in the household increases by one member, it increases the human capital index or human capital of the household by 1.439 units. This is maybe due to the reason that households with employed members significantly influence the per capita income and thus uplift the standard of living of the household [Abbas (2000) and Ali et al., (2012)].

Coefficient of the variable show that an increase in household size by one person will result in falling the human capital index or human capital of the household by 0.351 units. A household with a large family size has a low income per capita and therefore spends less on well-being. This study supports the findings of Becker and Lewis (1973), Becker and Tomes (1976), Desai (1995) and Baranowska-Rataj et al., (2015).

The value of the constant is -3.516 . The R-squared of this model is 59.0 percent and the values of Fstatistics are 106.636, with having p-value is 0.000 .

Table 3: OLS Regression Results of Human Capital, Poverty and Economic Development Nexus in Multan Division

\begin{tabular}{|l|c|c|c|c|}
\hline \multicolumn{2}{|c|}{ Dependent Variable: Human Capital INDEX (HCI) } \\
\hline \multicolumn{1}{|c|}{ Variable } & Standard & & \\
Enstant & Coefficients & $\begin{array}{c}\text { Errors } \\
\text { t-Statistic }\end{array}$ & p-value \\
\hline Poverty & -3.516 & 2.275 & -1.545 & 0.123 \\
\hline Per Capita Income & -0.951 & 0.399 & -2.383 & 0.018 \\
\hline Remittances & 1.113 & 0.238 & 4.675 & 0.000 \\
\hline Number of Earners in the Household & 0.756 & 0.327 & 2.312 & 0.021 \\
\hline Household Size & 1.439 & 0.119 & 12.125 & 0.000 \\
\hline R-squared & -0.351 & 0.049 & -7.129 & 0.000 \\
\hline F-statistic & 0.590 & Adjusted R-squared & 0.584 \\
\hline
\end{tabular}

Diagnostic Test: Heteroskedasticity White Test

\begin{tabular}{lrlr}
\hline F-statistic & 1.368 & Prob. F(18,358) & 0.213 \\
Obs*R-squared & 67.893 & Prob. Chi-Square(18) & 0.232 \\
\hline
\end{tabular}

Source: Survey data, 2019

In Table 4, economic development is the dependent variable to analyze its relationship with household poverty and human capital in the Multan division. For this purpose, the per capita income of the household is employed as a proxy for economic development. The Ordinary Least Squares (OLS) regression technique is used for the econometric analysis.

To analyze the impact of household poverty on the per capita income of the households, the econometric results show a negative relationship between household poverty and economic development. The 
coefficient of household poverty shows if the poverty of a household rises to one unit, it decreases the income per capita or economic development of the households by 1.166 percent. This relationship is found to be statistically significant. Poor households mostly live in rural areas and live below the poverty line due to low wages [ Amjad and Kemal (1997) and Hilson (2009).

Focusing on the effect of human capital on economic development or per capita income of the households in the Multan division, the econometric results show a positive relationship between human capital and economic development, statistically significant. From Table 4, the results conclude that if the human capital index or human capital increases by 1 unit, it will increase the per capita income or economic development of the household by 0.045 percent. Better education and health facilities are required by poor households to upsurge their per capita income. Improvement in skill will further provide opportunities for the poor household to earn a better livelihood [ Lee and Lee (1995)]. The initial levels of education reduce household poverty and foster economic growth (Datt and Ravallion,1998).

About the occupation of the household in the primary sector, the study concludes the negative relationship between the income per capita and occupation of the household in the primary sector, significant statistically. If the occupation of the respondent in the primary sector increase by one unit, it will lead to reducing the income per capita of the household or economic development by 0.204 percent. It has been observed that occupations in the primary sector have low earning potential. Some farm households are unable to generate other nonfarm sources of income and therefore rely on low per capita income and subsistence lifestyles. This study supports the finding of Jirström et al., (2011).

The greater the family size, the lower will be the per capita income, significant statistically at a 10 percent significance level. the finding from Table 9.4 reveals that an increase in household size by one person will lessen the income per capita or economic development of the household by 0.014 percent [Jansen et al., (2006), Tuyen et al., (2014), Jin and Xie (2017)].

The coefficient of remittances is found to be statistically insignificant and no relation between economic development and remittances has been found. The value of the constant is 9.278. The R-squared of this model is 75.5 percent and the values of F-statistics are 231.660, having a p-value of 0.000 . To investigate the presence of Heteroskedasticity, the White test indicates that there is no issue of Heteroskedasticity.

Table 4: OLS Regression Results of Economic Development, Poverty and Human Capital Nexus in Multan Division

\begin{tabular}{|c|c|c|c|c|c|}
\hline \multicolumn{6}{|c|}{ Dependent Variable: Per Capita Income (LNPCI) } \\
\hline Variable & & Coefficients & $\begin{array}{c}\text { Standard } \\
\text { Errors }\end{array}$ & $\begin{array}{c}\mathrm{t}- \\
\text { Statistic }\end{array}$ & p-value \\
\hline Constant & & 9.278 & 0.100 & 92.338 & 0.000 \\
\hline Poverty & & -1.166 & 0.057 & -20.361 & 0.000 \\
\hline Human Capital & & 0.045 & 0.009 & 4.949 & 0.000 \\
\hline Remittances & & 0.018 & 0.068 & 0.264 & 0.792 \\
\hline Occupation of the Household & & -0.204 & 0.051 & -4.033 & 0.000 \\
\hline Household Size & & -0.014 & 0.009 & -1.672 & 0.095 \\
\hline R-squared & & 0.757 & \multicolumn{2}{|c|}{$\begin{array}{l}\text { Adjusted R- } \\
\text { squared }\end{array}$} & 0.754 \\
\hline F-statistic & & 231.660 & \multicolumn{2}{|c|}{ Prob(F-statistic) } & $(0.000)$ \\
\hline \multicolumn{6}{|c|}{ Diagnostic Test: Heteroskedasticity White Test } \\
\hline F-statistic & 1.570 & \multicolumn{2}{|c|}{ Prob. F(17,359) } & & 0.113 \\
\hline Obs*R-squared & 9.911 & \multicolumn{3}{|c|}{ Prob. Chi-Square(17) } & 0.127 \\
\hline
\end{tabular}

Source: Results are estimated based on Survey data, 2019

\section{Conclusion}

This case study has been conducted in the Multan division. The data has been collected from 377 households to analyze the nexus between poverty, human capital and economic development in the Multan 
division. The study concludes that in the poverty model, household size, household head's occupation in the primary sector shows a positive relationship with the household's poverty. However human capital of the household can play a major role in alleviating poverty in the Multan division. In the human capital model, the findings show that per capita income, worker's remittances, number of earners in the household can play a vital role in accelerating the human capital of the households. However, poverty and household size show a negative relationship with the human capital of the households in the Multan division. The findings of the economic development model show that poverty, household size, occupation of the household's head in the primary sector reduce the per capita income. However, human capital helps to increase the per capita income of the household in the Multan division. Worker's remittances are failed to show any major contribution to the economic development of this division.

\section{References}

Abbas, Q. (2000). The Role of Human Capital in Economic Growth: A Comparative Study of Pakistan and India. The Pakistan Development Review, 39 (4), 451-473.

Adekoya, O. D. (2018). Impact of Human Capital Development on Poverty Alleviation in Nigeria. International Journal of Economics \& Management Sciences, 7(4), 1-8.

Adenutsi, D. E. (2010) Long-Run Macroeconomic Impact of International Migrant Remittances on Human Development in Low-Income Countries: A Panel Analysis of Sub-Saharan Africa. Journal of International Economic Studies 24, 113-132.

Agenor, P. (1996). The Labor Market and Economic Adjustment, IMF Staff Papers 32, 261- 335.

Akinbode, S, O. (2013). Profiles and Determinants of Poverty Among Urban Households in South-West Nigeria. American Journal of Economics, 3(6), 322-329.

Ali, S., Chaudhry, I, S., \& Farooq, F. (2012). Human Capital Formation and Economic Growth in Pakistan. Pakistan Journal of Social Sciences, 32, (1), 229-240.

Amjad, R., \& Kemal, A. R. (1997). Macroeconomic Policies and Their Impact On Poverty Alleviation in Pakistan. The Pakistan Development Review, 39-68.

Anyanwu, J. C. (2014). Marital Status, Household Size and Poverty in Nigeria: Evidence from The 2009/2010 Survey Data. African Development Review, 26(1), 118-137.

Arif, G. M., \& Bilquees, F. (2007). Chronic and Transitory Poverty in Pakistan: Evidence from A Longitudinal Household Survey. The Pakistan Development Review, 111-127.

Arif, G. M., \& Farooq, S. (2014). Rural Poverty Dynamics in Pakistan: Evidence from Three Waves of the Panel Survey. The Pakistan Development Review, 53(2), 71-98.

Attanasio, O., Meghir, C., Nix, E., \& Salvati, F. (2017). Human Capital Growth and Poverty: Evidence from Ethiopia and Peru. Review of Economic Dynamics, 25, 234-259.

Baranowska-Rataj, A., Styrc, M., \& Da Silva, G. C. (2015). The Impact of Family Size On Educational Attainment in Cross-Country Comparative Perspective.

Becker, G. S. (1995). Human Capital and Poverty Alleviation. World Bank, Human Resources Development and Operations Policy

Becker, G. S., \& Lewis, H. G. (1973). On The Interaction Between the Quantity and Quality of Children. Journal of Political Economy, 81(2, Part 2), S279-S288.

Becker, G. S., \& Tomes, N. (1976). Child Endowments and The Quantity and Quality of Children. Journal of Political Economy, 84(4, Part 2), S143-S162.

Benhabib, J., \& Mark M. Spiegel. (1994). The Role of Human Capital in Economic Development: Evidence from Aggregate Cross-Country Data. Journal of Monetary Economics, 34, 143-173.

Datt, G., \& Jolliffe, D. (1999). Determinants of Poverty in Egypt, 1997 (No. 75). International Food Policy Research Institute (IFPRI).

Datt, G., \& Ravallion, M. (1998). Farm Productivity and Rural Poverty in India. The Journal of Development Studies, 34(4), 62-85.

Desai, S. (1995). When Are Children from Large Families Disadvantaged? Evidence from Cross-National Analyses. Population Studies, 49(2), 195-210.

Frankel, J \& Romer, D. (1999). Does Trade Cause Growth? American Economic Review, 89 (3), 379-399.

Government of Pakistan (2015-16). National Poverty Report. Planning Commission of Pakistan, 


\section{Islamabad.}

Government of Pakistan (2015-16). Pakistan Economic Survey. Federal Bureau of Statistics, Islamabad. Government of Pakistan (2016-17). Pakistan Economic Survey. Federal Bureau of Statistics, Islamabad. Government of Pakistan (2016-17). Multidimensional Poverty in Pakistan. Ministry of Planning, Development and Reform. Islamabad.

Government of Pakistan (2017-18). Pakistan Economic Survey. Federal Bureau of Statistics, Islamabad. Government of Pakistan (2018-19). Pakistan Economic Survey. Federal Bureau of Statistics, Islamabad. Greene, W. H. (2003). Econometric Analysis. Pearson Education India.

Gujarati, D. (2012). Econometrics By Example. Macmillan.

Hilson, G. (2009). Small-Scale Mining, Poverty and Economic Development in Sub-Saharan Africa: An Overview. Resources Policy, 34(1-2), 1-5.

Jansen, H. G., Pender, J. L., Damon, A. L., \& Schipper, R. A. (2006). Land Management Decisions and Agricultural Productivity in The Hillsides of Honduras (No. 1004-2016-78474).

Jin, Y., \& Xie, Y. (2017). Social Determinants of Household Wealth and Income in Urban China. Chinese Journal of Sociology, 3(2), 169-192.

Jirström, M., A. Andersson and G. Djurfeldt. (2011). Smallholders Caught in Poverty - Flickering Signs of Agricultural Dynamism. In African Smallholders: Food Crops, Markets and Policy. (Eds Djurfeldt Et Al.) London: CABI. Chapter 4, Pp 74-106.

Knowles, S., \& Owen, P. D. (1995). Health Capital and Cross-Country Variation in Income Per Capita in The Mankiw-Romer-Weil Model. Economics Letters, 48(1), 99-106.

Lee, J. W., \& Francisco, R. H. (2010). Human Capital Accumulation in Emerging Asia, 1970-2030. Asian Development Bank Economics Working Paper Series, (216).

Lee, D. W., \& Lee, T. H. (1995). Human Capital and Economic Growth Tests Based On the International Evaluation of Educational Achievement. Economics Letters, 47(2), 219-225.

Litchfield, J. And Mcgregor, T. (2008). Poverty in Kagera, Tanzania: Characteristics, Causes and Constraints. PRUS Working Paper No.42. University of Sussex, Brighton. United Kingdom

Narayan, D. (2002). Bonds and Bridges: Social Capital and Poverty. Social Capital and Economic Development: Well-Being in Developing Countries. Northampton, MA: Edward Elgar, 58-81.

Narayan-Parker, D. (1999). Bonds and Bridges: Social Capital and Poverty (Vol. 2167). World Bank Publications.

Pede, V. O., Luis, J. S., Paris, T. R., \& Mckinley, J. D. (2011). Determinants of Household Income: A Quantile Regression Approach for Four Rice-Producing Areas in The Philippines. Asian Journal of Agriculture and Development, 9(1362-2016-107601), 65-76.

Rodriguez, A. G., \& Smith, S. M. (1994). A Comparison of Determinants of Urban, Rural and Farm Poverty in Costa Rica. World Development, 22(3), 381-397.

UNDP, M. (2018). Human Development Report. The 2016 Global Multidimensional Poverty Index (MPI).

Unicef. (2016). Ending Extreme Poverty: A Focus on Children. Sustainable Development Goals in Rich Countries.

Unicef. (2017). Global Nutrition Report 2017: Nourishing The SDG. Https://Data.Unicef.Org/Resources/Global-Nutrition-Report-2017-Nourishing-Sdgs

Warren, M. R., Thompson, J. P., \& Saegert, S. (2001). The Role of Social Capital in Combating Poverty. Social Capital and Poor Communities, 3, 1-28.

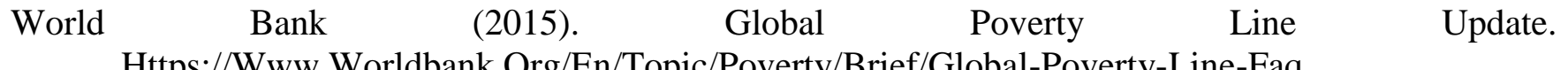

Https://Www.Worldbank.Org/En/Topic/Poverty/Brief/Global-Poverty-Line-Faq 